\title{
Methodology of the geoecological functional zoning of territories subjected to anthropogenic disturbance due to waste disposal
}

\author{
Stanislav Dubrova ${ }^{1 *}$, Sónia Chelinho ${ }^{2}$, Pavel Zelenkovskiy ${ }^{3}$, and Ivan Podlipskiy ${ }^{1}$ \\ ${ }^{1}$ Department of Geology and Geoecology, Herzen State Pedagogical University of Russia, 199034, \\ Moika river emb., 48, block 5, St. Petersburg, Russia \\ ${ }^{2}$ Centre for Functional Ecology - Science for People \& the Planet (CFE) Department of Life Sciences, \\ University of Coimbra, 3000-456, Calçada Martim de Freitas, Coimbra, Portugal \\ ${ }^{3}$ Department of Environmental Geology, Head of Department, Professor, Institute of Earth Sciences, \\ St. Petersburg State University, 199034, Universitetskaya emb., 7/9, St. Petersburg, Russia
}

\begin{abstract}
In the present contribution, the geochemical relationships of territorial units (landscapes), namely sewage sludge disposal sites and historical municipal solid waste landfills, that can be considered as chemical elements migration models and as dynamic components of ecological-geological systems (landfill site - adjacent area - recreation area)., is described. Since the study of pollutants migration in multicomponent systems is extremely time-consuming, the development of theoretical methods, able to simulate these processes, is of particular relevance. Therefore, in the present study, a geochemical model for substance migration in anthropogenically modified geoecological bodies and their surrounding was conceived, making use of complex mathematical processes and data analysis methodologies (parallel use of factor, cluster, canonical and discriminant analysis tools), and considering both geochemical specialization/composition of parent rocks and land use (functional geoecological zoning).
\end{abstract}

\section{Introduction}

With the increasing number of megacities, the constant expansion of their borders, and the often chaotic, unreasonable land-use planning, even those sites with potential recreational use suffer from enormous anthropogenic pressure. Geoecological assessments on the influence of various anthropogenic objects on the environment often reflect the level of negative impacts only and do not take into account relationships with other objects, e.g. those within the boundaries of the technosphere and those interacting with the upper horizons of the lithosphere. Moreover, the dimensions of sanitary protection zones do not

* Corresponding author: dubrova.stansilav@gmail.com 
take into account these features. In order to preserve ecosystems and assure the rational planning of urban development, it is necessary to pay special attention to the functional purpose and land use, which is the basis of zoning and urban management. The development of migration patterns in the matter flows (man-made and natural), considering objects and territories together, is the only method for justifying the state of ecosystems "downstream". It is fundamental to use the standard amount of geochemical information used in geoecological and engineering-ecological surveys for the characterization of geochemical communication, as a "flow" of substances migration, i.e., as a dynamic component of geoecological systems with no need for additional and time-consuming research. The main goal of the present study was to present an updated complex methodology for geo-ecological functional zoning of territories and their environmental impact assessment using a particular case-study, consisting of territories subjected to different levels of anthropogenic impact. The proposed approach allows the optimal ratio of use and/or protection measures to be set for a particular city site - the basic unit of a city territorial administration, acting as an essential tool for metropolis land resources management.

\section{Materials and methods}

The present study includes "exceptional objects" (geoecological anthropogenically modified objects of different genesis) with distinct eco-geochemical characteristics [5], located in "exceptional conditions" - within the catchment area of the Lakhta spill, flowing into the Gulf of Finland (Fig. 1). Representative sites of three different functional geoecological zones in St. Petersburg were selected, on the basis of close geomorphological, geological and hydrogeological conditions, but with distinct levels of anthropogenic impact, namely:

1. Industrial functional zone (Historical Municipal Solid Waste Landfill (MSWL) "Novoselki" (food and packaging waste, packaging, waste paper, household and office garbage) and Sewage Sludge Landfill "Severny" (SSL) (solid fraction of waste water, consisting of organic, mineral substances and a complex of microorganisms (excess activated sludge), hereafter designated as "Industrial (MSWL+SSL)". It consists of territories occupied by industrial enterprises, landfills as well as their correspondent sanitary protection zones and also transport infrastructures. 212 soil samples (53 sampling points times four horizons - 0-0.2 $\mathrm{m}, 0.2-1.0 \mathrm{~m}, 1.0-2.0 \mathrm{~m}, 2.0-3.0 \mathrm{~m}$ );

2. Residential functional zone (adjacent to the landfills area (MSWL+SSL), hereafter designated as "Residential". This zone is a transition between industrial and recreational areas and it is used for residential and business development purposes. (102 sampling points times four horizons);

3. Recreational functional zone (Novoorlovskaya Special Economic Zone (SEZ), a part of Novoorlovsky Forest Park), hereafter designated as "Recreational". This area was the reference for the geochemical background and it is a green area, mainly used for recreational purposes 235 soil samples (112 sampling points times four horizons). 


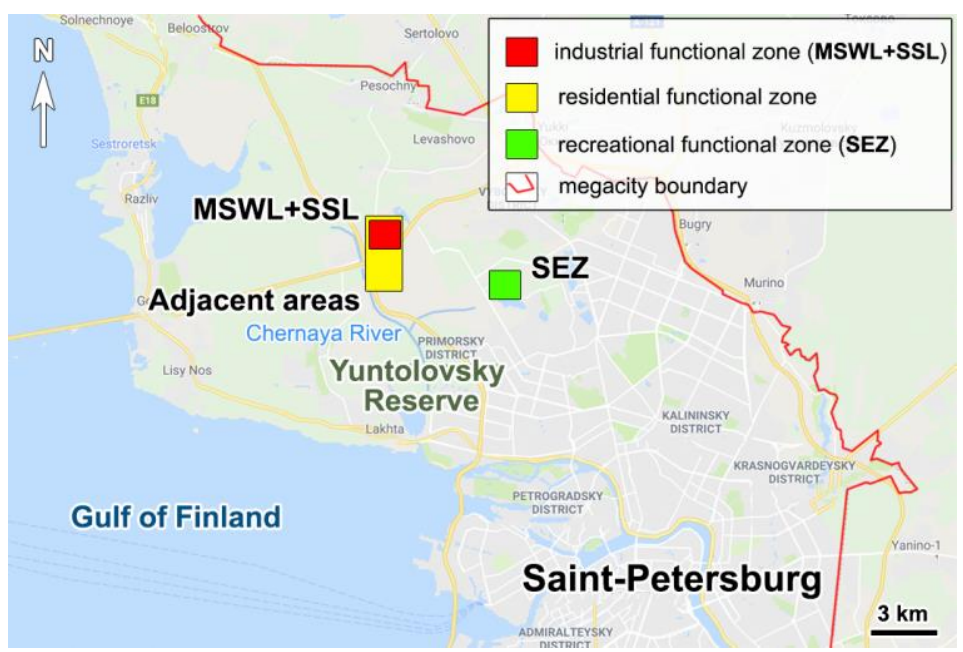

Fig. 1. Schematic map of the study areas

To assess the contamination of soils analysis for the presence of two organic compounds (petroleum and polycyclic aromatic hydrocarbon (PAH) - benzo (a) pyrene) and 10 heavy metals (mercury, lead, arsenic, cadmium, zinc, nickel, cobalt, chromium, copper, manganese) were performed. The analysis of the three matrices (soil) were determined by the Research Park of SPbU "Environmental Safety Observatory" by atomic absorption spectrometry (AAS) for heavy metals [4]. The determination of benzo (a) pyrene in the soil was carried out by high performance liquid chromatography using a chromatograph with fluorimetric detection [3]. Concentrations of petroleum were determined by the fluorimetric method on the "Fluorat-02" liquid analyzer.

To evaluate the degree of contamination of the study areas, the measured concentrations of both organic and metal contaminants were compared with the maximum permissible concentration (MPC) or approximate allowable concentration (APC). Another benchmark to assess and compare the levels of chemical pollution is the "background" content. The assessment of the danger of soil contamination for public health, due to metals were also carried out using the total pollution $(\mathrm{Zc})$ indicator. According to the available standards, the soils were included in category 1 (permissible), 2 (moderately dangerous), 3 (dangerous) or 4 (extremely hazardous pollution) whenever the Zc is, respectively, lower than $16,>16<32$, $>32<128$ or higher than 128 .

\section{Results and discussion}

\subsection{Geo-environmental assessment}

The actual assessment of the levels of chemical pollution of the territories of domestic and industrial waste landfills was based on a comparison of the existing pollution with the regional and local background geochemical levels for the objects, as well as maximum permissible concentrations (MPC). On the territory of MSWL, the concentrations of pollutants in all the studied horizons remain at a high level, exceeding the MPC for individual elements up to 50 times: $\mathrm{Pb}-1580 \mathrm{mg} / \mathrm{kg}$, As $-80 \mathrm{mg} / \mathrm{kg}, \mathrm{Cd}-24 \mathrm{mg} / \mathrm{kg}, \mathrm{Zn}$ - $1000 \mathrm{mg} / \mathrm{kg}, \mathrm{Ni}-300 \mathrm{mg} / \mathrm{kg}, \mathrm{Cr}-10000 \mathrm{mg} / \mathrm{kg}$, benzo (a) pyrene $-0.27 \mathrm{mg} / \mathrm{kg}$. According to the degree of chemical pollution, the soils of the territory of the Novoselki landfill, in all horizons, are considered as "extremely dangerous": the content of organic compounds of the first hazard class exceeds 5 MPC, the total pollution indicator taking into 
account toxicity (Zc) of pollutants takes values over 128 (Fig. 2). On the territory of the storage site of SSL, Zc values are significantly lower than those fixed at MSWL and range from 3.3 to 820 in the upper levels of $0.0-0.2 \mathrm{~m}$ and $0.2-1.0 \mathrm{~m}: \mathrm{Pb}-111 \mathrm{mg} / \mathrm{kg}$, As -20 $\mathrm{mg} / \mathrm{kg}, \mathrm{Cd}-50 \mathrm{mg} / \mathrm{kg}, \mathrm{Zn}-1000 \mathrm{mg} / \mathrm{kg}, \mathrm{Ni}-105 \mathrm{mg} / \mathrm{kg}, \mathrm{Cr}-206 \mathrm{mg} / \mathrm{kg}$, benzo (a) pyrene $-0.07 \mathrm{mg} / \mathrm{kg}$. Also, at a depth of 2.0-3.0 m, the maximum permissible concentrations of As were exceeded 2 times, $\mathrm{Cd}-9$ times, $\mathrm{Zn}-3$ times. The pollution halo is located in the horizons at $1 \mathrm{~m}$ deep, in the "old" north-western part of the silt sites.

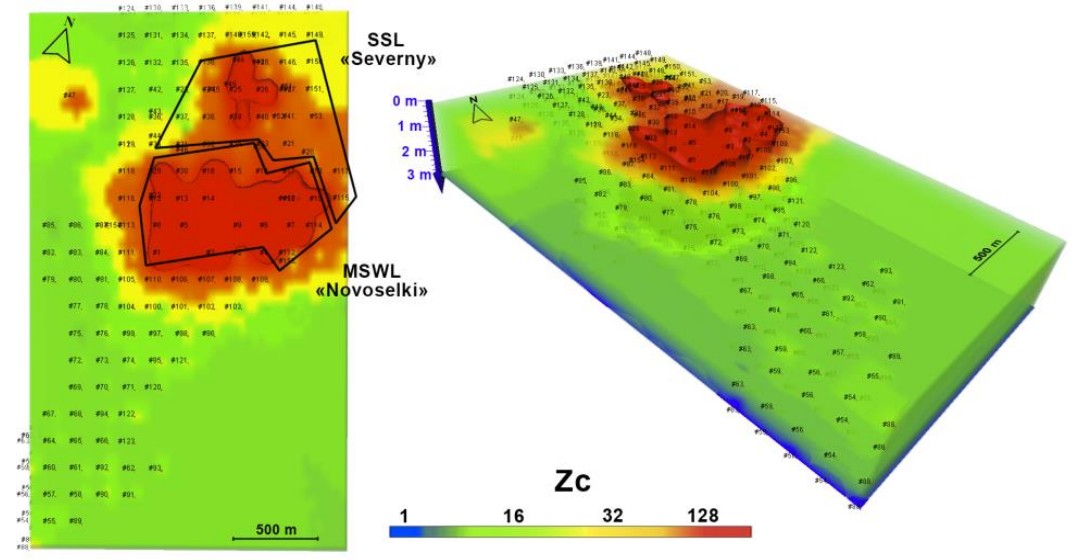

Fig. 2. $2 \mathrm{D}$ and $3 \mathrm{D}$ schemes of the distribution of soil $\mathrm{Z}_{\mathrm{c}}$ values in the territory of MSWL and SSL relative to the regional background.

\subsection{Multivariate statistical analysis}

In order to perform the geochemical portraits of the functional zones under study, as well as the subsequent creation of geochemical models, a canonical analysis was carried out. This approach enables the reduction of the initial geochemical data and highlight the most significant variables for each of the geoecological objects $[1,2]$. Historical MSW landfills, the most contrasting geoecological objects from a geochemical point of view, are ideally suited for modeling the flow of anthropogenic load. Forest park recreation zones under similar natural conditions are the best standards for modeling the geochemical background. An essential assumption of the method of geochemical modeling is that the identification signs of the industrial functional zone fully, accurately and consistently reflect the anthropogenic load. Such assumption can be further compensated with the creation of a geochemical portrait database, including various geoecological objects under different environmental conditions, that is, by maximizing the distinctive features of the evaluation set (Table 1).

Table 1. Formatting sections, subsections and subsubsections.

\begin{tabular}{|c|c|c|}
\hline Study Areas & Significant variables & Non-significant variables \\
\hline MSWL "Novoselki" & $\mathrm{Ni}$ & $\begin{array}{c}\mathrm{Hg}, \mathrm{Pb}, \mathrm{As}, \mathrm{Cd}, \mathrm{Zn}, \mathrm{Co}, \mathrm{Cr}, \mathrm{Cu}, \\
\mathrm{Mn}, \mathrm{Benz}, \mathrm{Petrol}\end{array}$ \\
\hline SSL " Severny" & $\mathrm{As}, \mathrm{Pb}, \mathrm{Co}$ & $\mathrm{Cd}, \mathrm{Zn}, \mathrm{Ni}, \mathrm{Cu}, \mathrm{Mn}, \mathrm{Benz}, \mathrm{Petrol}$ \\
\hline Adjacent areas & $\mathrm{Pb}, \mathrm{Cr}, \mathrm{Hg}, \mathrm{Ni}, \mathrm{Petrol}, \mathrm{Zn}$ & $\mathrm{Cu}, \mathrm{Benz}$ \\
\hline SEZ "Novoorlovskaya" & $\mathrm{Cu}, \mathrm{Zn}, \mathrm{Pb}, \mathrm{Mn}$ & $\mathrm{Hg}, \mathrm{Cd}, \mathrm{Ni}, \mathrm{Co}, \mathrm{Cr}$ \\
\hline
\end{tabular}

For geochemical monitoring studies, you can include an explanation of the percentage scale, that divides the set of probabilities into the following classes: $0-30 \%$ - the probability of anthropogenic load is absent (geochemical background for the object of study); $31-50 \%$ - 
the probability of anthropogenic load is possible; $51-70 \%$ - the probability of anthropogenic load is insignificant; $71-100 \%$ - the probability of anthropogenic load is present (Fig. 3).

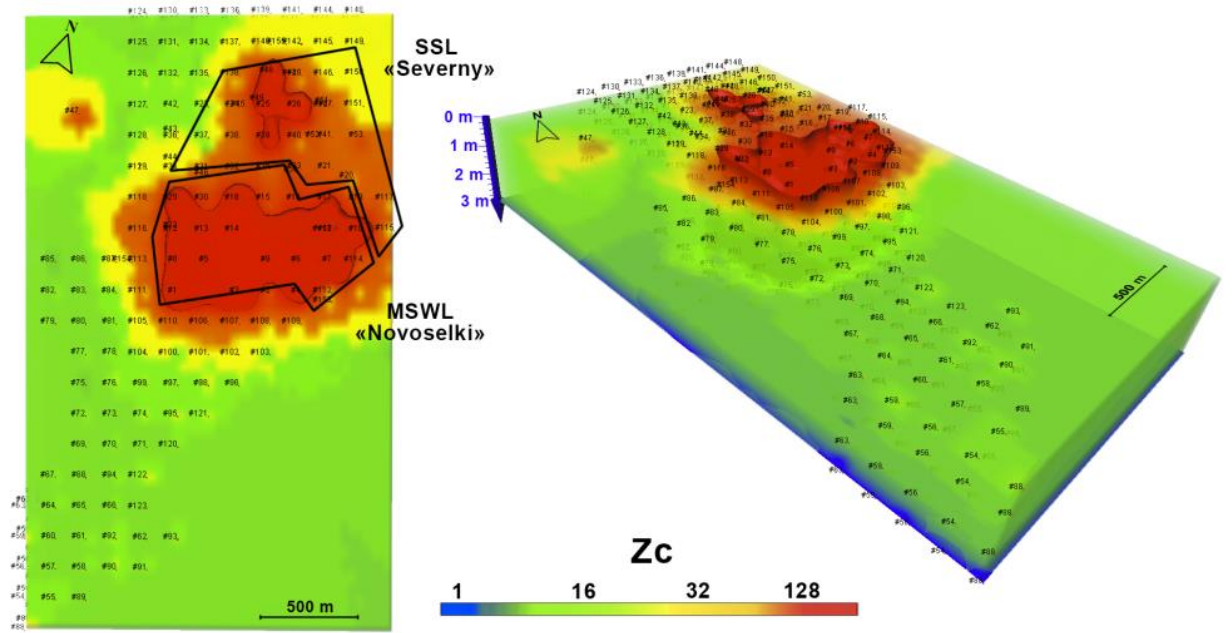

Fig. 3. 2D and 3D schemes of the probability distribution of anthropogenic load on the residential functional area of the first group study areas

The likelihood of anthropogenic load from the "Novosleki" landfill is observed along the bypass trenches of the landfill, along the channel of the Chernaya River, in the southwest direction by lowering the relief and located at 2 meters deep. At Northeast of the sewage sludge landfill, in the area of peat bogs, the estimates also point for anthropogenic load.

\section{Conclusions}

In the present study, within the framework of the functional zoning of the city's territories, detailed geochemical series of pollutants and three-dimensional geochemical maps of the study areas have been created. A significant improvement was the use of a multi-stage method for processing the high volume of geochemical data obtained from engineering and environmental surveys [6]. Indicator pollutants for each of anthropogenically modified geoecological objects and paragenetic associations for functional zones were identified. The presented methodological approach can be recommended for cadastral work. The simple and universal characteristics of the methodology make it possible to compile both smallscale maps of megalopolises and municipal areas, as well as large-scale maps of individual groups of sites. The necessary information database is based on a standard set of assessment criteria (sampling depth, scale of the testing grid) adopted in engineering and environmental surveys for construction and interstate standards.

\section{References}

1. R.E. Dashko, Y.A. Karpova, J. Min. Inst. (2014)

2. S.V. Dubrova, I.I. Podlipskiy, V.V. Kurilenko, W. Siabato, Environ. Pollut., 197, (2015) http://dx.doi.org/10.1016/j.envpol.2014.12.013

3. J.P. Durand, N. Petroff, J. Chromatogr. A., 190, 1 (1980) https://doi.org/10.1016/S00219673(00)85514-4 
4. A. Maurya, L. Kesharwani, M.K. Mishra, IJRASET, 6, VI (2018) https://doi:10.22214/ijraset.2018.6173

5. N. Mora-Naranjo, J.A Meima., A. Haarstrick, D.C. Hempel, Waste Manage., 24, 763773, (2004) https://doi.org/10.1016/j.wasman.2004.04.006

6. M. Vorenhout, N.M. VanStraalen, H.J.P. Eijsackers, Environ. Toxicol. Chem., 19, (2000) https://doi.org/10.1002/etc.5620190901 